\title{
Corn Bunting Miliaria calandra populations, landscape and land-use in an arable district of eastern England
}

\author{
CHRISTOPHER F. MASON and SHEILA M. MACDONALD
}

\begin{abstract}
Summary
A study of Corn Buntings Miliaria calandra, a rapidly declining red-listed species in the United Kingdom, was conducted over five years in the intensively cultivated, arable landscape of north-east Essex, eastern England. Mean densities in study plots ranged from 8 to 15 territories per $\mathrm{km}^{2}$, with evidence of a decline over the five years. A total of 278 singing males was located in $247 \mathrm{~km}^{2}$ of farmland, some $2-3 \%$ of the U.K. population and therefore of national significance. The distribution of territories was highly clumped and there was marked territory fidelity between years. There was a strong preference for territories encompassing field boundaries without hedges and a general avoidance of hedges. Territories occupied in four or five years were more likely to contain water-filled ditches and/or weedy farm tracks than territories occupied in a single year. Song posts may be important resources. There was little preference shown for particular crops or other land-uses during the breeding season. During the winter period there was a strong selection for feeding on the small amount of grass, and in the late winter period, on stubbles. Lack of feeding opportunities in winter would appear to be critical to Corn Buntings. It is suggested that a retention of stubbles over winter on the $26 \%$ of farmland destined for spring sowing could be highly beneficial to Corn Bunting populations and that this could be initially targeted at those areas currently holding dense breeding populations.
\end{abstract}

\section{Introduction}

Annual censuses of breeding birds in the United Kingdom have shown that 13 species which live largely on farmland declined by an average of $30 \%$ between 1968 and 1995 (Siriwardena et al. 1998). The decline in the Corn Bunting Miliaria calandra began in the early 1980s (Marchant et al. 1990) and the species is now red-listed in terms of conservation concern (Gibbons et al. 1996), having declined by $76 \%$ over the period 1968-1991 (Fuller et al. 1995). There have also been decreases in Corn Bunting populations in the Netherlands, Belgium, Sweden, Denmark, Germany, Austria, Switzerland and Czechoslovakia (Donald 1997).

The decline in bird populations is generally considered to be the result of agricultural intensification, though the precise factors causing the decrease in numbers of individual species are poorly understood and the evidence is largely circumstantial. The key changes in agriculture that are implicated are the switch from spring-sown to autumn-sown crops, the loss of mixed farms and traditional rotations, the increased use of herbicides and insecticides, land drainage and the 
improvement of grass yields, and the removal of hedgerows. This intensification of agriculture is likely to have reduced the availability of seeds and invertebrates to birds (Donald 1998, Wilson et al. 1999). Other factors, such as climate change or predation, may have also played a role in declines of the Corn Bunting but there is no convincing evidence (Donald 1997).

The current paper presents data from a five year study of Corn Buntings in north-east Essex, eastern England, a region of intensive, largely arable farming. It forms part of a wider study of the impacts of landscape and land-use on farmland birds (Mason 1998, Mason and Macdonald 1999a, b, 2000). The distribution of Corn Bunting territories in relation to landscape and cropping patterns is described and a full census of territories in the district is presented. Habitat use by winter flocks was examined. We suggest some measures which might reverse the decline of the species in lowland Britain.

\section{Study area and methods}

The study was carried out in the Tendring district of north-east Essex, U.K. $\left(51^{\circ} 50^{\prime} \mathrm{N}, 1^{\circ} 10^{\prime} \mathrm{E}\right)$, a peninsula of $325 \mathrm{~km}^{2}$, of which $247 \mathrm{~km}^{2}$ is farmed. It is bounded by the estuary of the River Stour to the north, the estuary of the River Colne to the south and the North Sea to the east. The town of Colchester lies on the western boundary of the district. The agriculture is predominantly arable, occupying some $63 \%$ of the area, with an additional $13 \%$ grassland, most of it improved. Woodland occupies $5.6 \%$ of the total, with the built-up area comprising $14 \%$ and minor habitats (water, wasteland, etc.) making up the remainder.

The climate of the Tendring district is more continental than in most of Britain, with a low annual rainfall (average $510 \mathrm{~mm}$, but lower than that in the study years), higher summer temperatures and colder winters than average for lowland England.

\section{Breeding season study}

Ten tetrads $\left(2 \mathrm{~km} \times 2 \mathrm{~km}\right.$, total area $\left.40 \mathrm{~km}^{2}\right)$ within the peninsula were selected randomly. Prior to the start of the study the areas of major landscape features (built, woodland, etc.) were determined from maps (1:25,000). Field boundaries were mapped by field survey and classified as without hedges (though they often contained scattered bushes), hedges averaging less than $1.5 \mathrm{~m}$ tall (whether continuous or with gaps) and hedges averaging more than $1.5 \mathrm{~m}$ tall (continuous or with gaps). Land-use was determined on a field-by-field basis during bird surveys in the first three years of the study.

All tetrads were visited on at least four occasions between mid-April and midJuly in 1994-1998 inclusive. All roads, farm tracks and footpaths, providing good access to all farmed habitats in the tetrads, were slowly walked, main surveys beginning in the early morning and being completed by 1ohoo GMT. Additional visits were made in the morning and mid-afternoon in late July in an attempt to confirm territories of birds for which there had been only a single registration. The nature and height of song posts were noted during the first three years of study. In each year the position of all male Corn Buntings assessed to be holding territories was plotted on maps $(1: 12,500)$. In this polygynous species the number 
of territories cannot be directly related to the number of pairs. Birds were considered to be holding territories if they were singing (the main recorded activity), or behaved in an agitated manner without flying away on the approach of the observer. Wet and windy weather was avoided for surveys. Standard conventions were used to record activities (Bibby et al. 1992). Territories were assigned in relation to the distribution of clusters of registrations on maps. Territories were accepted only if there were two or more registrations; single registrations were considered to represent itinerant males.

\section{Corn Buntings outside of the breeding season}

A pilot study indicated that few Corn Buntings would be found by transect surveys. Corn Buntings were therefore recorded opportunistically. The size of flocks was recorded. The habitat was noted where flocks were feeding. Singing birds were also noted.

\section{Full census of Corn Buntings within the district}

In 1997 and 1998 the whole district was surveyed for singing Corn Buntings. The area was divided into tetrads, which were surveyed in random order. All roads, tracks and footpaths were walked during the morning or late afternoon during fine sunny weather and the position of all singing Corn Buntings was plotted on maps. Singing birds heard on adjacent tetrads were also mapped. This meant that, although each quadrat was walked only once, most of the area was censused at least twice because of the long distance over which Corn Buntings can be heard in fine weather in this terrain.

\section{Results}

Corn Buntings in the breeding season

The landscape features and land-use of the 10 tetrads are summarized in Tables 1 and 2. More than 90\% of the land was farmed. Tetrads had an average of 14.9 $\mathrm{km}$ of hedgerows and $12 \mathrm{~km}$ of field boundaries without hedges, though there was considerable variation between tetrads.

Autumn-sown crops, predominantly wheat and barley, comprised on average $58 \%$ of the cultivated area (Table 2 ). A range of spring-sown crops, but especially sugar beet, peas and potatoes, occupied $26 \%$ of the cultivated area. There was a small proportion of grass, while only $4 \%$ of land was "set-aside" (arable land taken out of cultivation). Minor cultivations included market gardens, soft fruit, etc.

The densities of Corn Bunting territories over the five year study period are given in Table 3. One tetrad never held Corn Buntings while two others held single territories in only some years. Even in tetrads with relatively high populations, the distribution was patchy, with apparently clumped distributions and large areas of seemingly suitable habitat never holding territories during the study period. Mean densities, calculated from $\log (n+1)$ transformed data, ranged from 8 to 15 males $\mathrm{km}^{-2}$ over the study period but sign tests between consecutive 
Table 1 . Landscape features of the 10 study tetrads

\begin{tabular}{lcc}
\hline & Mean/tetrad & Range \\
\hline Field boundaries without hedges $(\mathrm{km})$ & 12.02 & $2.03-19.41$ \\
Hedges $(\mathrm{km})$ & & \\
Gappy $(<1.5 \mathrm{~m}$ tall) & 2.11 & $0-2.95$ \\
Complete $(<1.5 \mathrm{~m}$ tall) & 0.24 & $0-1.49$ \\
Gappy $(>1.5 \mathrm{~m}$ tall) & 10.30 & $3.34-24.76$ \\
Complete $(>1.5 \mathrm{~m}$ tall) & 2.25 & $0.12-5.61$ \\
Total hedge & 14.90 & $5.55-31.09$ \\
Farmed area (ha) & 366.16 & $345.3-390.5$ \\
Non-farmed area (ha) & 33.84 & $9.5-54.7$ \\
Scrub & 0.64 & $0-4.8$ \\
Woodland & 3.47 & $0-10.9$ \\
Water & 0.74 & $0.2-2.4$ \\
Residential area (buildings and gardens) & 7.95 & $5.4-9.8$ \\
Orchards & 2.47 & $0-13.6$ \\
Roads & 21.04 & $3.0-31.7$ \\
\hline
\end{tabular}

Table 2. Area (ha) of crops in the study tetrads

\begin{tabular}{lrrrr}
\hline & 1994 & 1995 & 1996 & Overall \% \\
\hline Autumn-sown crops & 1843 & 1872 & 1964 & 57.6 \\
Wheat & 979 & 1001 & 1175 & 32.0 \\
Barley & 762 & 740 & 678 & 22.1 \\
Oilseed rape & 80 & 128 & 109 & 3.2 \\
Other & 21 & 3 & 3 & 0.2 \\
Spring-sown crops & 932 & 860 & 799 & 26.3 \\
Sugar beet & 219 & 174 & 199 & 6.0 \\
Peas & 196 & 110 & 119 & 4.3 \\
Beans & 39 & 44 & 23 & 0.8 \\
Potatoes & 183 & 227 & 221 & 6.4 \\
Salad crops & 32 & 39 & 44 & 1.2 \\
Oilseed rape & 73 & 78 & 43 & 2.0 \\
Linseed & 8 & 63 & 56 & 1.3 \\
Cereals & 101 & 92 & 69 & 2.7 \\
Other & 81 & 33 & 25 & 1.4 \\
Grass & 264 & 308 & 326 & 8.6 \\
Set-aside land & 150 & 143 & 135 & 4.3 \\
Minor cultivations & 69 & 51 & 34 & 1.5 \\
\hline
\end{tabular}

Table 3. Mean density (on log-transformed data) in 10 tetrads of Corn Bunting territories and density range

\begin{tabular}{llllll}
\hline & 1994 & 1995 & 1996 & 1997 & 1998 \\
\hline Mean density/1o km² & 15 & 15 & 11 & 8 & 10 \\
Range/1o km & $0-58$ & $0-75$ & $0-48$ & $0-55$ & $0-68$ \\
\hline
\end{tabular}


years revealed no significant differences between territory densities. Nevertheless, regressions of numbers of territories in individual tetrads against time revealed significant trends of decline in two $(b=-2.3, t=-5.19 ; b=-1.2, t=-4.24$ respectively, $P<0.05$ ), while no tetrads showed increasing populations. From the mean densities, the population for the district as a whole (farmed area 247 $\mathrm{km}^{2}$ ) was estimated at a peak of 376 territories in 1995 and a low of 229 territories in 1997 .

The number of years over which territories were occupied was determined by overlaying territory maps. Some $44.4 \%$ of territories were occupied in only one year, $21.2 \%$ in two years, $16.7 \%$ in three years, $11.1 \%$ in four years and $6.6 \%$ in all five years of the study. Territory fidelity was greatest in those parts of the tetrads where territories were most clumped.

Examples of clumped distributions of territories are given in Figure 1 and the overall distribution of distances between territory centres in Table 4. The distribution of nearest-neighbour distances for each year was tested with a goodness-of-fit test (Campbell and Clark 1971, see Krebs 1998). $\chi^{2}$ values obtained were $647,836,450,613$ and 174 for $1994-1998$ respectively $\left(d \mathrm{f}=4\right.$, expected $\chi^{2}=$ $18.47, P<0.001$ in all cases). Territories are highly clumped, some $57 \%$ of territories being within $100 \mathrm{~m}$ of their nearest neighbour.

The field boundaries contained within corn bunting territories were classified as without hedges, though they often contained isolated shrubs or trees, hedges less than $1.5 \mathrm{~m}$ tall and hedges taller than $1.5 \mathrm{~m}$. The results of the combined five years of study are given in Table 5 . The majority of territories included boundaries without hedges. The proportions of boundaries in the territories were compared with the proportion in the study area and the results were highly significant $\left(\chi^{2}=114, d f=2, P<0.001\right)$. The distribution of territories in the boundary classes in individual years was also examined using a preference index, Jacobs $D$ ( Jacobs 1974):

$$
D=r-\mathrm{p} / r+p-2 r p
$$

where $r$ is the proportion in the sample and $p$ is the proportion in the habitat. The results are shown in Table 5. Clearly the absence of a hedgerow is preferred by Corn Buntings, which show a general avoidance of hedgerows. The preference for open landscapes is also demonstrated by a positive correlation between total territories recorded over the study period in a quadrat and the mean field size for the quadrat $(r=0.89, d f=8, P<0.001)$. Typical landscapes preferred and avoided by Corn Buntings are shown in Figure 2.

It may be that, holding territories in such open landscapes, song posts become important resources. The song posts used by Corn Buntings when first located, together with the height above ground of the singing bird, are given in Table 6 . Corn Buntings sang from a range of song posts at a variety of heights, ranging from weeds at $0.5 \mathrm{~m}$ to the tops of electricity pylons. The most frequently used song posts were isolated trees and electricity or telephone wires, $10-20 \mathrm{~m}$ above ground. Wires made up $85 \%$ of song posts higher than $10 \mathrm{~m}$ and are clearly important for male advertisement in this rather featureless landscape.

To examine the influence of land-use on the distribution of Corn Bunting territories the frequency of land-use in territories was determined and compared with the frequency of land-use within the study area using the Jacobs $D$ preference 

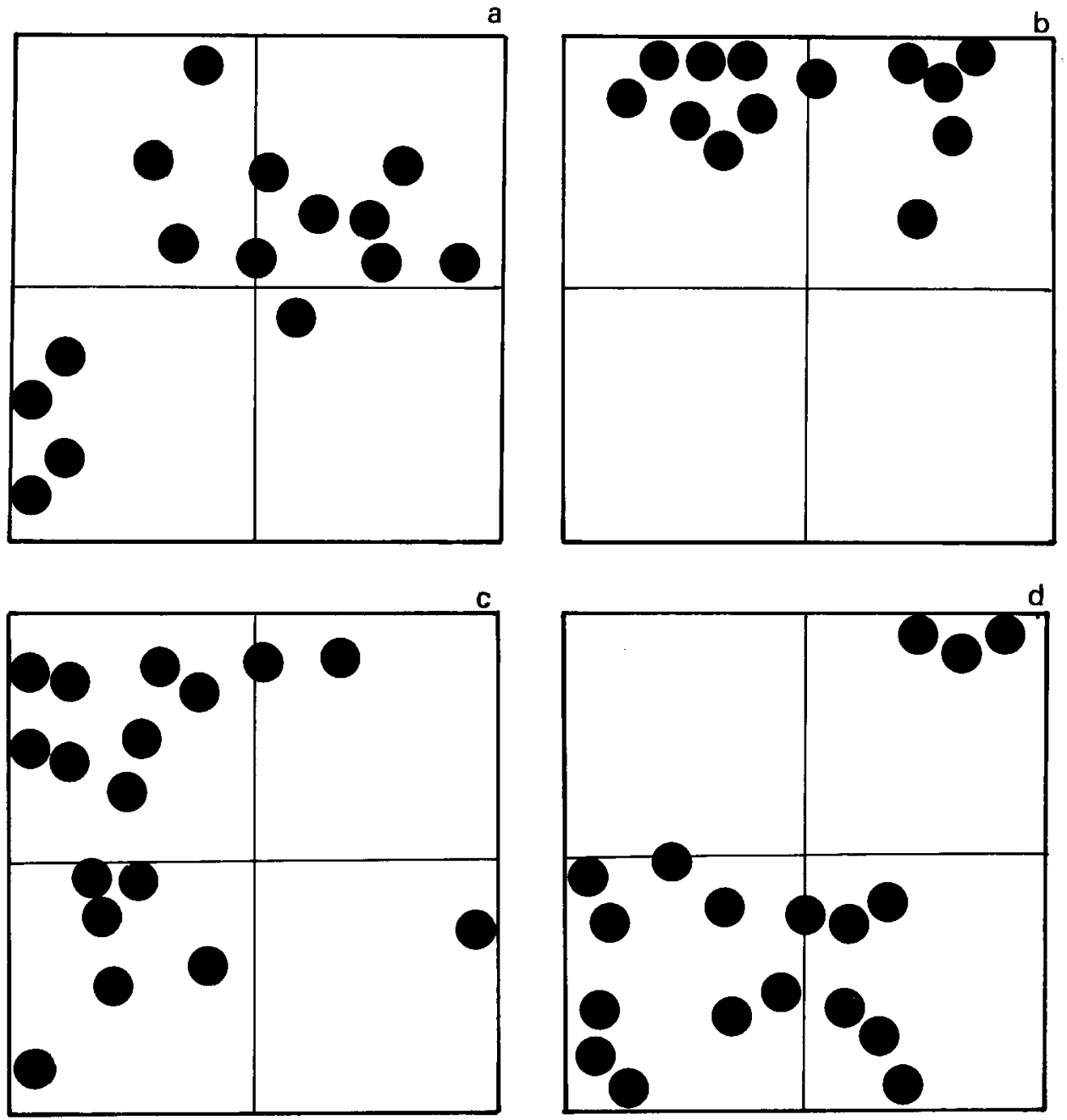

Figure 1. Examples of clumped distributions of Corn Bunting territories (represented as dots) within tetrads ( $2 \mathrm{~km} \times 2 \mathrm{~km}$ squares): (a) tetrad 1, 1997; (b) tetrad 4, 1996; (c) tetrad 6, 1996; (d) tetrad 71996.

Table 4. Nearest-neighbour distances $(\mathrm{m})$ between centres of Corn Bunting territories $(n=450)$

\begin{tabular}{llllll}
\hline Distance $(\mathrm{m})$ & $0-50$ & $51-100$ & $101-200$ & $201-300$ & $>300$ \\
$\%$ territories & 34.4 & 22.2 & 22.2 & 11.1 & 10.0 \\
\hline
\end{tabular}

index (Table 7). Winter-sown crops were the most frequent crop type within territories but there was no preference for these crops, apart from a slight preference for oilseed rape, which occupies only $3 \%$ of the farmed area. Similarly there was no preference for spring-sown crops, apart from linseed, which again occupied only $1.3 \%$ of the farmed area. There was a slight avoidance of pasture and 
Table 5. Overall proportion of boundary types enclosed within Corn Bunting territories $(n=476)$ and preference index shown for boundary types in the five years

\begin{tabular}{lccc}
\hline & Without hedges & Hedges $<1.5 \mathrm{~m}$ & Hedges $>1.5 \mathrm{~m}$ \\
\hline Territories (\%) & 82.1 & 3.4 & 14.6 \\
Jacobs D & & & \\
1994 & +0.55 & -0.22 & -0.52 \\
1995 & +0.80 & -0.58 & -0.77 \\
1996 & +0.69 & -0.41 & -0.67 \\
1997 & +0.74 & -0.75 & -0.67 \\
1998 & +0.80 & -0.59 & -0.78 \\
\hline
\end{tabular}

Table 6. Percentages of types of song post used by Corn Buntings and heights above ground of singing birds $(n=352)$

\begin{tabular}{lr}
\hline Song post & \\
Crop & 9.4 \\
Weed in crop & 11.4 \\
Hedge & 1.7 \\
Boundary bush & 6.5 \\
Boundary tree & 27.0 \\
Fence post & 4.0 \\
Pylon & 2.6 \\
Wire & 35.8 \\
Other & 1.7 \\
Height above ground & \\
$<1 \mathrm{~m}$ & 23.0 \\
$>1-5 \mathrm{~m}$ & 21.6 \\
$>5-10 \mathrm{~m}$ & 18.2 \\
$>10-20 \mathrm{~m}$ & 35.8 \\
$>20 \mathrm{~m}$ & 1.4 \\
\hline
\end{tabular}

no preference for set-aside land. Agricultural land-use therefore appeared to have no influence on the distribution of Corn Bunting territories.

Some territories were occupied in all five years of the study, suggesting that they may have particularly good resources. In 1998 the following features were recorded on those territories which were occupied in at least four years and compared with those recorded in territories which were occupied in a single year: hedge (gappy or complete), bushes, trees, power lines, water-filled ditches, weedy tracks (providing access for farm machinery), weedy field boundaries, permanent weeds in fields. The results are summarized in Table 8. There was a significant difference in the overall frequencies of the categories between the two samples $\left(\chi^{2}=16.4, d f=8, P<0.05\right)$. The permanent territories significantly more often contained water-filled ditches $\left(\chi^{2}=5.12, d f=1, P<0.05\right)$ and weedy tracks $\left(\chi^{2}=6.39, d f=1, P<0.01\right)$, while the territories occupied in a single year contained weedy field boundaries significantly more often $\left(\chi^{2}=9.71, d f=1, P<0.01\right)$.

Corn Buntings in the district generally nest late, with some males still singing vigorously on territories to the end of the first week of August. For example, 10 of 13 territories were still known to be active in quadrat 1 at the beginning of August 1994. Breeding success is therefore potentially at risk from harvesting 
Table 7. Frequency (\%) of crop types within Corn Bunting territories (1994-1996) and mean preferences (Jacobs $D \pm \mathrm{SE}$ ) for crops

\begin{tabular}{lcll}
\hline & $\%$ & $D$ & SE \\
\hline Autumn-sown crops & 58.1 & +0.01 & 0.017 \\
Wheat & 29.4 & -0.06 & 0.061 \\
Barley & 22.6 & -0.01 & 0.051 \\
Oilseed rape & 5.3 & +0.23 & 0.07 \\
Other & 0.8 & - & - \\
Spring-sown crops & 31.5 & +0.13 & 0.021 \\
Barley & 1.9 & -0.05 & 0.158 \\
Potatoes & 6.6 & +0.02 & 0.018 \\
Oilseed rape & 2.8 & +0.17 & 0.095 \\
Peas & 5.7 & +0.10 & 0.207 \\
Sugar beet & 4.9 & -0.11 & 0.113 \\
Linseed & 2.8 & +0.36 & 0.144 \\
Other & 6.8 & - & - \\
Pasture & 4.9 & -0.35 & 0.157 \\
Set-aside land & 5.3 & +0.03 & 0.162 \\
Other & 0.2 & - & - \\
\hline
\end{tabular}

Table 8. Frequency (\%) of habitat features in territories of Corn Buntings occupied permanently (in at least four years; $n=55$ ) and temporarily (only once; $n=32$ )

\begin{tabular}{lcc}
\hline & $\begin{array}{c}\text { Permanent } \\
\text { territories }\end{array}$ & $\begin{array}{c}\text { Temporary } \\
\text { territories }\end{array}$ \\
\hline Hedge, complete & 12.7 & 21.9 \\
Hedge, gappy & 21.8 & 18.8 \\
Boundary shrubs & 32.7 & 25.0 \\
Boundary trees & 36.4 & 56.3 \\
Powerlines/wires & 45.5 & 43.8 \\
Water & 29.1 & 6.3 \\
Weedy track & 61.8 & 31.3 \\
Weedy field boundary & 47.2 & 81.3 \\
Permanent weeds in fields & 43.6 & 37.5 \\
\hline
\end{tabular}

activities. The potato harvest begins in the first week of June and continues throughout the summer. Winter oilseed rape is cut in the second week of July, while barley and peas are harvested in the third week of July, followed by wheat in the first week of August. The ploughing of barley stubbles begins in the first week of August. Although we did not systematically observe nests, we frequently flushed female birds from patches of weeds at the edge of farm tracks. On a number of occasions we observed birds taking nesting material or food to patches of weeds around the bases of electricity poles and pylons which crossed large fields, such patches not being harvested. On 25 July 1994, a female was watched collecting straw from a harvested barley field and carrying to such a site beneath an electricity pole. 
Table 9. Distribution of flock sizes $(n=88)$ of Corn Buntings in winter

\begin{tabular}{lllll}
\hline Flock size & $2-5$ & $6-10$ & $11-50$ & $>50$ \\
$\%$ & 42.0 & 20.4 & 28.4 & 9.1 \\
\hline
\end{tabular}

\section{Corn Buntings outside the breeding season}

Some male Corn Buntings appear to hold territories throughout the winter. Single birds were regularly heard in full song from late October through November, then infrequently until the third week in February, when song again became regular. Birds would also sing in groups while perched on wires. A total of 70 flocks (i.e. a group of two or more birds) was recorded during the study period between October and May. There was no significant difference between flock sizes in the first (October-December) and second (January-May) winter periods so the data were combined (Table 9). Many birds occurred in groups of five or less but some large flocks were recorded, the largest being of 133 in November. Significant flocks were still present in May. For example a flock of 90 birds was seen feeding in peas on 2 May 1996, with another flock of 60 birds in an adjacent field of set-aside land. The latest spring flock recorded was of 20 birds feeding on grass on 28 May.

Many flocks were observed on wires but for those observed feeding, preferences were determined using Jacobs $D$, the proportion of flocks in land-use types being compared with the proportion of land-use in the district (from data in Mason and Macdonald 1999b). The results are summarized in Table 10. Winter cereals were generally avoided. There was selection for plough in the first winter period, stubbles, especially in the second period when it comprised only $3.5 \%$ of the land cover, and a strong selection in both periods for the small amount of grass.

\section{Full census of Corn Buntings}

The distribution of Corn Bunting territories in the district in 1997-1998 is shown in Figure 3. A total of 278 singing males was located. Virtually none was found on the western boundary of the district. The population was distributed in distinct clusters. Two clusters lie on flat, coastal cultivation on either side of the town of Clacton-on-Sea. The other major group lies along a north-west to southeast axis on a low-lying plateau of large arable fields. There are smaller groups between these centres on another flat area of large fields. Corn Buntings were scarce in gently undulating countryside.

\section{Discussion}

Intensively cultivated arable land dominates the landscape in the study area, autumn-sown cereals occupying more than half of the farmed area. The intensification of agriculture, so called industrial farming, has resulted in the simplification of the landscape. For example in the parish of Wivenhoe, immediately adja- 

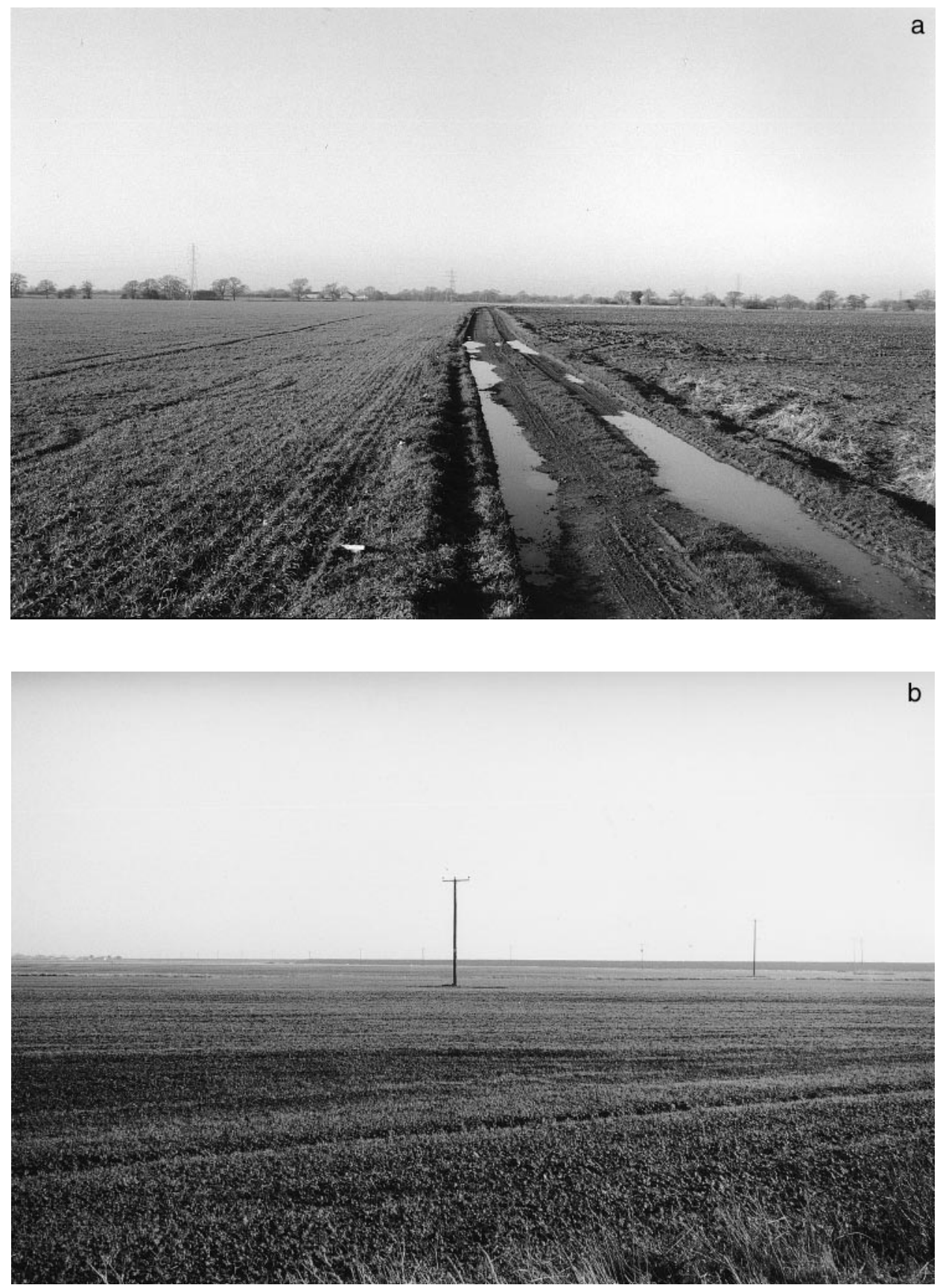

cent to the study district and to tetrad $5,49 \%$ of hedgerows were removed between 1879 and 1960, with a further $16 \%$ between 1960 and 1980, while $59 \%$ of boundary trees were lost over the period (Mason et al. 1987). Within the Tendring district as a whole, such losses in landscape elements are typical (C.F.M. unpubl. data). 


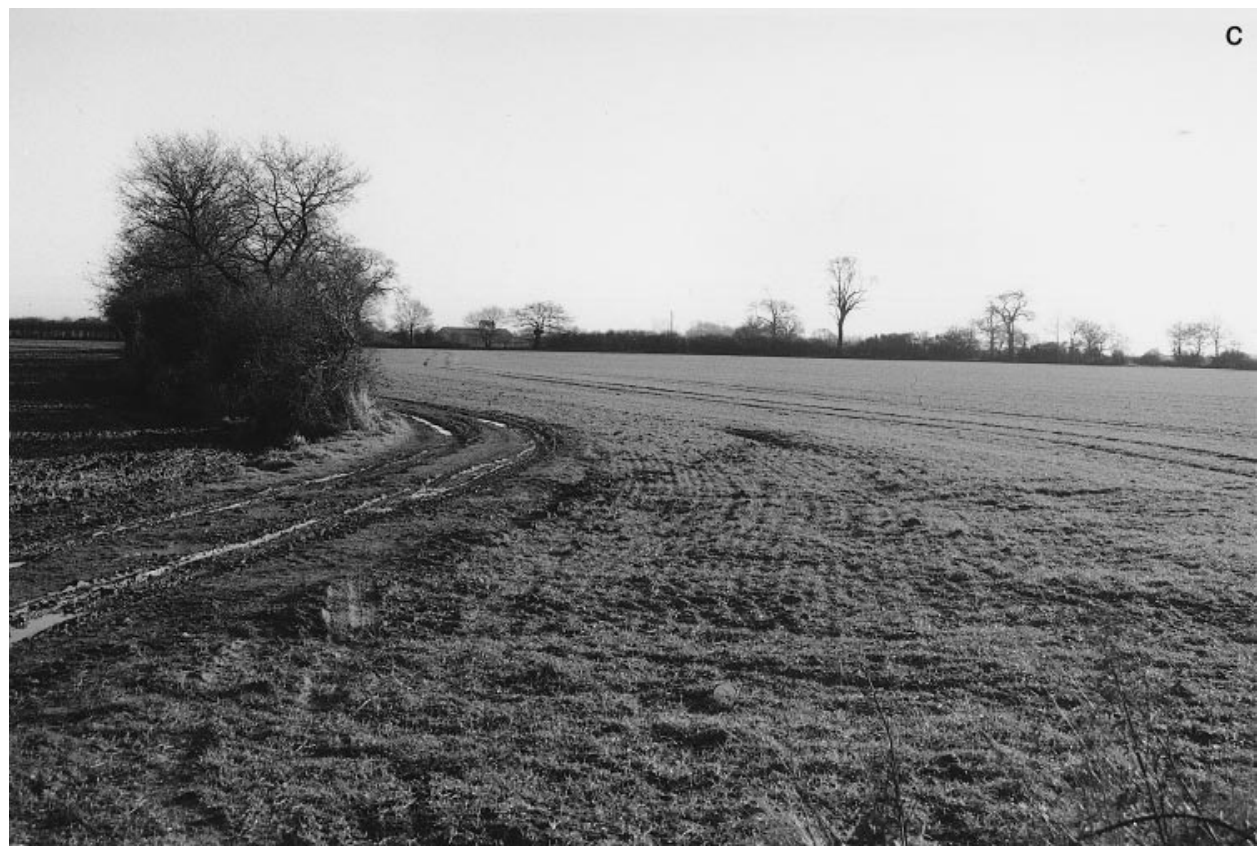

Figure 2. Typical landscapes in the study area. (a) Tetrad 4, with an average field size of 10.2 ha and a hedge density of $32 \mathrm{mha}^{-1}$; this track, edged by weeds, especially Heracleum sphondyllium, held up to six Corn Bunting territories in $700 \mathrm{~m}$. (b) Tetrad 7, with an average field size of 11.1 ha and a hedge density of $14 \mathrm{mha}^{-1}$; up to nine territories were recorded along $900 \mathrm{~m}$ of this track, with adjacent telephone wires and electricity lines and pylons. (c) Tetrad 5, with an average field size of 6.3 ha and a hedge density of $77 \mathrm{mha}^{-1}$; Corn Buntings were never recorded in this tetrad. Photographs were taken in December.

Table 10. Land-use preferences (Jacobs D) of winter flocks of Corn Buntings

\begin{tabular}{lccc}
\hline Land-use & \% of flocks & $\begin{array}{c}D \text { in first } \\
\text { winter period }\end{array}$ & $\begin{array}{c}D \text { in second } \\
\text { winter period }\end{array}$ \\
\hline Stubble & 30.0 & +0.30 & +0.87 \\
Plough & 16.7 & +0.50 & -0.31 \\
Winter cereals & 10.0 & -0.39 & -1.00 \\
Sugar beet & 3.3 & +0.25 & NP \\
Grass & 40.0 & +0.58 & +0.85 \\
\hline
\end{tabular}

NP, not present.

During the full census of the district during 1997 and 1998, 278 territories were recorded, which is close to the extrapolation of 247 territories from the tetrad survey of 1998 . The overall population density of 1.2 territories $\mathrm{km}^{-2}$ is somewhat higher than the $0.4 \mathrm{~km}^{-2}$ recorded in the most densely populated areas during the national survey in 1993 (Donald and Evans 1995). Populations in individual tetrads were as high as 7.5 territories $\mathrm{km}^{-2}$. A study area in Lincolnshire held 2.76 territories $\mathrm{km}^{-2}$ (Gillings and Watts 1997), while previously arable land in southern England newly planted with grasses typical of chalk downland had 


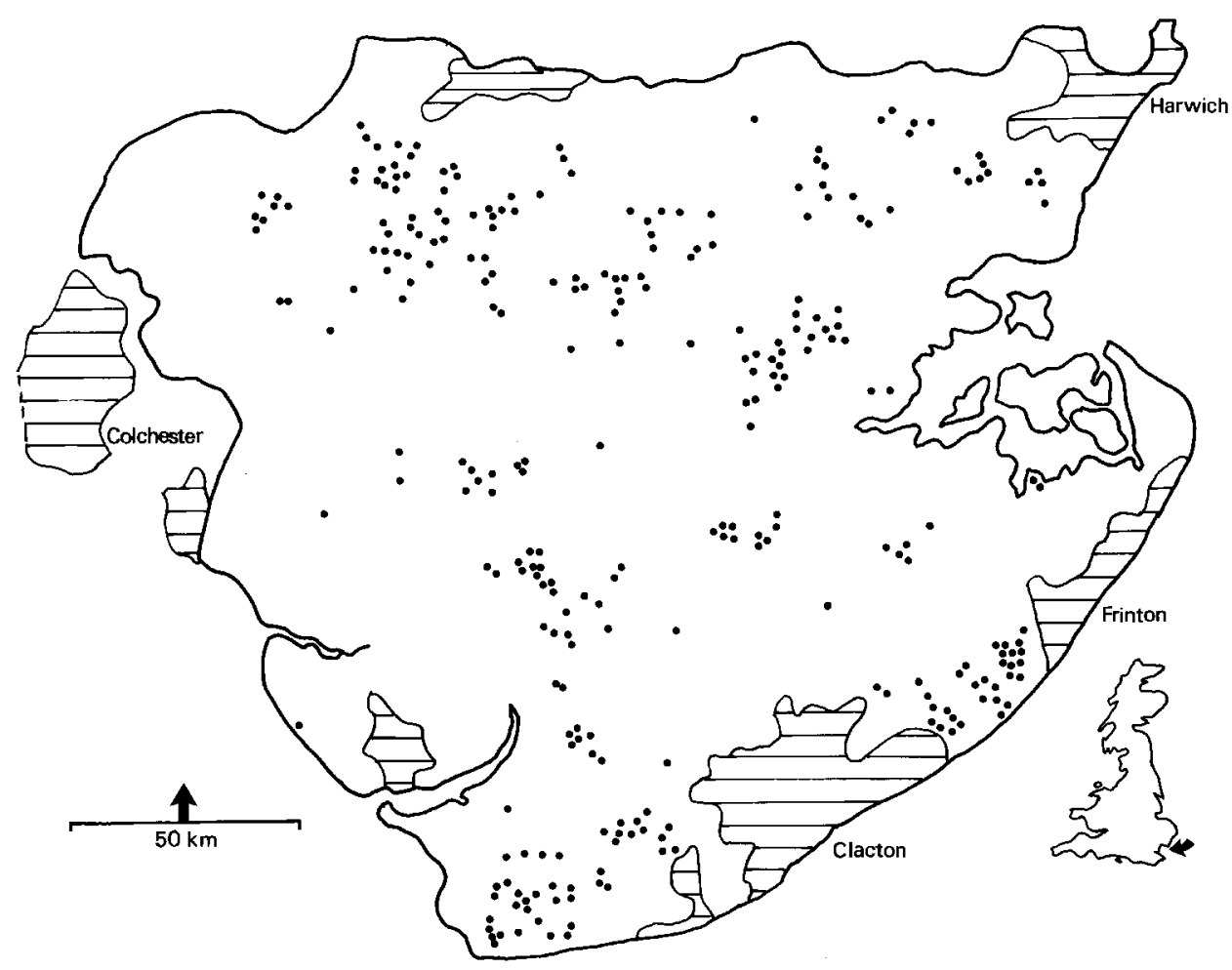

Figure 3. The distribution of Corn Bunting territories in Tendring District, north-east Essex, eastern England (the hatched areas delineate towns).

territory densities of $5.7-7.0 \mathrm{~km}^{-2}$ (Wakeham-Dawson 1997). Populations in south-west Germany had densities of $0.5-1.2$ territories $\mathrm{km}^{-2}$, with up to 6.4 territories $\mathrm{km}^{-2}$ in the centre of the breeding range (Eislöffel 1997). The most productive areas in the Tendring peninsula would therefore appear currently to hold some of the densest populations in northwest Europe.

The overall density, however, hides a very patchy distribution within the district. There appear to be several more or less discrete populations, with a scattering of territories between. The main groups are situated in open, flat countryside (see below), similar to that described for south-west Germany by Eislöffel (1997). Two are coastal, the others situated on the central plateau of the district. The distribution may represent a source-sink metapopulation structure (Hanski and Gilpin 1991), as suggested for the British population as a whole by Donald and Evans (1995). These five areas of dense populations may produce surplus birds which repopulate other areas but which operate as population sinks because their productivity is too low to be self-sustaining. However, even within the dense populations there appear to be suitable patches without territories.

There is evidence that the population of Corn Buntings was in decline during the five year study period. While mean populations did not change on tetrads, due to the extremes of population density they represented, two individual tet- 
rads showed a trend of decline while none showed an increase. The overall decline was 33\% between 1994 and 1998, similar to that described by Bashford (1999) from the Breeding Bird Survey of the British Trust for Ornithology. The population of Corn Buntings in Britain was estimated as 20,000 in 1993 (Donald and Evans 1995), so the Tendring population, at $1.4 \%$ of the British population, is of national significance. However, taking into account the decline described by Bashford (1999), the population in Tendring at the end of the study period could have held $2.4 \%$ of the population of this once widespread species.

Some Corn Buntings in the district held territories through the winter, presumably established males on high-quality territories (Møller 1983). Others did not settle until June, with flocks recorded into late May. A considerable number of territories were occupied over a number of years, probably those offering the highest quality resources. Thus $17 \%$ were occupied in three years, an occupancy also recorded on South Uist, western Scotland by Shepherd et al. (1997). A five year occupancy rate of $7 \%$ is also in agreement with the Danish study of Møller (1983).

The open nature of the landscape occupied by Corn Buntings in the district is demonstrated by the strong preference for selecting territories which encompass hedgeless field boundaries, with a general avoidance of hedges, especially those taller than $1.5 \mathrm{~m}$. In a Cambridgeshire study area the majority of a small number of territories located were associated with hedges of about $1 \mathrm{~m}$ high (Sparks et al. 1996). The landscape preferences seem in marked contrast to those in a another study in eastern England, in the Lincolnshire Fens, where the majority of territories was associated with smallholdings (farms of less than 200 ha), which were farmed less intensively and with greater crop diversity than in other parts of the study area (Gillings and Watts 1997). In Tendring, territory densities are greatest on the most intensively cultivated land with low crop diversity.

Two features associated with the most persistent territories were weedy tracks and water-filled ditches. Ditches and tracks were important features in Corn Bunting territories in south-west Germany (Eislöffel 1997) and water-filled ditches in parts of the Netherlands (Hustings 1997). Ditches were favoured foraging localities in Lincolnshire (Gillings and Watts 1997). It is likely that these weedy field boundaries hold much higher densities of invertebrate prey, particularly caterpillars (Lepidoptera and Symphyta) and beetles (Coleoptera), favoured as food for nestlings (Aebischer and Ward 1997, Brickle and Harper 1999). Densities of invertebrates are low in autumn-sown cereals (Aebischer and Ward 1997). The weeds are also likely to provide safe nest sites (see below).

There was little evidence for any selection of crops. There was a slight preference for oilseed rape and an avoidance of pasture but other crops, as well as set-aside land, were represented in territories in proportion to their presence in tetrads. Territories tend to be fixed irrespective of crop rotation, as also noted by Hartley et al. (1995), the landscape features discussed above presumably being of greater significance. Pasture was avoided in South Uist (Hartley and Shepherd 1997) but other forms of grassland were preferred in southern England (Aebischer and Ward 1997, Wakeham-Dawson 1997) and the Iberian Peninsula (Diaz and Tellería 1997). In the Tendring study area, an 18 ha field of coastal conservation grassland, mown in late July and holding a large population of 
Skylarks Alauda arvensis (Mason and Macdonald 2000), never held Corn Bunting territories, despite its apparent suitability, though flocks did forage there in late winter. Set-aside land was a preferred habitat in the most intensively farmed areas of north-east Germany (Fischer and Schöps 1997). Winter barley was selected in Lincolnshire (Gillings and Watts 1997) and spring barley in southern England (Aebischer and Ward 1997) but cereals were strongly avoided in Spain (Diaz and Tellería 1997). Watson and Rae (1997) stressed the importance of weedy fields in Corn Bunting territories in north-east Scotland. Such weediness is scarce in our study area, the weeds along tracks and water-filled ditches probably having a similar function.

The apparent regional differences in landscape and land-use preferences suggest that populations of Corn Buntings adapt to local conditions in their summer nesting habitats. These clearly need to be determined at the local scale before any policy to improve habitat for the species can be implemented successfully.

There is evidence of an increase in nest losses in Corn Buntings due to farming practices with the switch to autumn-sown crops, and hence earlier harvesting (Crick et al. 1994), though overall nest productivity has increased (Crick 1997). Although we did not search for nests, our impression was that the majority were along tracks or ditches, or in weeds around posts and beneath pylons which were not cultivated. Hartley and Shepherd (1997) found that most nests were in uncultivated land while Gillings and Watts (1997) reported no losses of nests due to farming activities. It seems likely that losses due to earlier harvesting are unlikely to be significant at the population level.

Corn Buntings proved difficult to find outside of the breeding season using standard survey methods so records were collected opportunistically. Many flocks were located on wires and could not be related with certainty to a particular feeding site. Of those that were, grasslands, especially those near the coast, were preferred feeding sites throughout the winter, while stubbles were also important, especially in the second winter period. Grass makes up less than 10\% of the farmed land-use in the Tendring district, while stubbles occupy only 3.5\% in the second half of the winter (Mason and Macdonald 1999b). Shrubb (1997) examined historical trends in Corn Bunting populations and concluded that undersown stubbles were important to the species, providing an assured food supply in winter. In a broad survey of habitat requirements in winter it was found that stubbles, especially those rich in weeds, were strongly preferred, whereas cereals and plough were strongly avoided, with grass used in proportion to its availability (Donald and Evans 1994). Winter stubbles have also been shown to be important to Corn Buntings in north-east Scotland (Watson and Rae 1997) and Norfolk, eastern England (Robinson and Sutherland 1997) and for seed-eating birds generally (Wilson et al. 1996, Buckingham et al. 1999, Mason and Macdonald 1999b). Corn Buntings in the Iberian Peninsula also selected winter stubbles, but with larger numbers on grasslands, though this may be a reflection of the small number of available stubbles rather than better feeding conditions (Diaz and Tellería 1997). This may also be true in the present area, where it was suggested for wintering birds generally that there was just too little suitable habitat to enable birds to remain throughout the winter (Mason and Macdonald 1999b). Food availability in winter is likely to be a critical factor in controlling numbers of Corn Buntings, as also concluded by Donald (1997). 


\section{Conclusion}

The evidence from this and other studies suggests that food availability in winter, and especially the loss of winter stubbles, has played a key role in the decline of Corn Buntings. Although birds may be more selective of summer habitats than studies have thus far revealed, there nevertheless appears to be sufficient of that type of habitat which currently supports dense Corn Bunting populations to indicate that it may not be limiting. By contrast, only 3-4\% of the land area is left as stubbles in our study area by the turn of the year, although some $26 \%$ of the area is under spring cultivation (Mason and Macdonald 1999a,b), the land being ploughed long before it is sown. Clearly, if the land destined for spring cultivation could be left untended from harvest until early spring, it could have major benefits to the Corn Bunting population in this district.

The main reasons for early ploughing are that heavy land is more difficult to plough in late winter, the weathering of soil exposed to frosts produces a good seed bed, and the lack of manpower on modern farms requires that ploughing is done at a time which maximizes efficiency (R.E. Lord and R.F. Whitmore, pers. comm.). On the negative side, early ploughing renders exposed soil prone to erosion by wind and water, a severe problem in eastern England (Pretty 1998, Pretty et al. 2000). The relative benefits and costs of early ploughing, irrespective of their costs to birds, have not been determined. Incentives, such as Arable Stewardship Schemes, to encourage the retention of winter stubbles are urgently required on a scale larger than those currently being trialled. Nevertheless, modern stubbles are much poorer in weed seeds than those of thirty or more years ago because of the use of herbicides. Subsidies to manage a proportion of the farmed area specifically for birds may be the best way forwards, at least in the short term until more radical changes in farming practice becomes more acceptable (Mason and Macdonald 2000). For seed-eating birds such as Corn Buntings this might require growing a cereal crop rich in weeds, which could for example be harvested as food for organically produced poultry or pigs. With Tendring district now holding nationally important Corn Bunting numbers, the majority in a few discrete populations, the specific targeting of actions could have benefits whose success could be readily measured against the population census data reported here.

\section{References}

Aebischer, N.J. and Ward, R.S. (1997) The distribution of corn buntings Miliaria calandra in Sussex in relation to crop type and invertebrate abundance. Pp. 124-138 in P.F. Donald and N.J. Aebischer, eds. The ecology and conservation of corn buntings Miliaria calandra. Peterborough: Joint Nature Conservation Committee (U.K. Nature Conservation, No. 13).

Bashford, R. (1999) The Breeding Bird Survey: the first five years. BTO News 224: 10-13.

Bibby, C.J. Burgess, N.D. and Hill, D.A. (1992) Bird census techniques. London: Academic Press.

Brickle, N.W. and Harper, D.G.C. (1999) Diet of nestling Corn Buntings in southern England examined by compositional analysis of faeces. Bird Study 46: 319-329.

Buckingham, D.L., Evans, A.D., Morris, A.J., Orsman, C.J. and Yaxley, R. (1999) Use of set-aside land in winter by declining farmland bird species in the UK. Bird Study 46 : 157-169. 
Campbell, D.J. and Clarke, D.J. (1971) Nearest neighbour tests of significance for nonrandomness in the spatial distribution of singing crickets (Teliogryllus commodus) (Walker). Anim. Behav. 19: 750-756.

Crick, H.Q.P. (1997) Long-term trends in corn bunting Miliaria calandra productivity in Britain. Pp. 52-64 in P.F. Donald and N.J. Aebischer, eds. The ecology and conservation of corn buntings Miliaria calandra. Peterborough: Joint Nature Conservation Committee (U.K. Nature Conservation, No. 13).

Crick, H.Q.P., Dudley, C., Evans, A.D. and Smith, K.W. (1994) Causes of nest failure among buntings in the UK. Bird Study 41: 88-94.

Diaz, M. and Tellería, J.K. (1997) Habitat selection and distribution of corn buntings Miliaria calandra in the Iberian Peninsula. Pp. 151-161 in P.F. Donald and N.J. Aebischer, eds. The ecology and conservation of corn buntings Miliaria calandra. Peterborough: Joint Nature Conservation Committee (U.K. Nature Conservation, No. 13).

Donald, P.F. (1997) The corn bunting Miliaria calandra in Britain: a review of current status, patterns of decline and possible causes. Pp. 11-26 in P.F. Donald and N.J. Aebischer, eds. The ecology and conservation of corn buntings Miliaria calandra. Peterborough: Joint Nature Conservation Committee (U.K. Nature Conservation, No. 13).

Donald, P.F. (1998) Changes in the abundance of invertebrates and plants on British farmland. Brit. Wildlife 9: 279-289.

Donald, P.F. and Evans, A.D. (1994) Habitat selection by Corn Buntings Miliaria calandra in winter. Bird Study 41: 199-210.

Donald, P.F. and Evans, A.D. (1995) Habitat selection and population size of Corn Buntings Miliaria calandra breeding in Britain in 1993. Bird Study 42: 190-204.

Eislöffel, F. (1997) The corn bunting Miliaria calandra in south-west Germany: population decline and habitat requirements. Pp. 170-173 in P.F. Donald and N.J. Aebischer, eds. The ecology and conservation of corn buntings Miliaria calandra. Peterborough: Joint Nature Conservation Committee (U.K. Nature Conservation, No. 13).

Fischer, S. and Schòps, A. (1997) Habitat selection by corn buntings Miliaria calandra in north-east Germany - the results of preliminary studies. Pp. 174-177 in P.F. Donald and N.J. Aebischer, eds. The ecology and conservation of corn buntings Miliaria calandra. Peterborough: Joint Nature Conservation Committee (U.K. Nature Conservation, No. 13).

Fuller, R.J., Gregory, R.D., Gibbons, D.W., Marchant, J.H., Wilson, J.D., Baillie, S.R. and Carter, N. (1995) Population declines and range contractions among lowland farmland birds in Britain. Conserv. Biol. 9: 1425-1441.

Gibbons, D., Avery, M., Baillie, S., Gregory, R., Kirby, J., Porter, R., Tucker, G. and Williams, G. (1996) Bird species of conservation concern in the United Kingdom, Channel Islands and Isle of Man: revising the Red Data List. RSPB Conserv. Rev. 10: 7-18.

Gillings, S. and Watts, P.N. (1997) Habitat selection and breeding ecology of corn buntings Miliaria calandra in the Lincolnshire Fens. Pp. 139-150 in P.F. Donald and N.J. Aebischer, eds. The ecology and conservation of corn buntings Miliaria calandra. Peterborough: Joint Nature Conservation Committee (U.K. Nature Conservation, No. 13).

Hanski, I. and Gilpin, M. (1991) Metapopulation dynamics: brief history and conceptual domain. Biol. J. Linn. Soc. 42: 3-16.

Hartley, I.R. and Shepherd, M. (1997) The behavioural ecology of breeding corn buntings Miliaria calandra on North Uist. Pp. 88-102 in P.F. Donald and N.J. Aebischer, eds. The ecology and conservation of corn buntings Miliaria calandra. Peterborough: Joint Nature Conservation Committee (U.K. Nature Conservation, No. 13).

Hartley, I.R., Shepherd, M. and Thompson, D.B.A. (1995) Habitat selection and polygyny in breeding Corn Buntings Miliaria calandra. Ibis 137: 508-514.

Hustings, F. (1997) The decline of the corn bunting Miliaria calandra in The Netherlands. Pp. 42-51 in P.F. Donald and N.J. Aebischer, eds. The ecology and conservation of corn 
buntings Miliaria calandra. Peterborough: Joint Nature Conservation Committee (U.K. Nature Conservation, No. 13).

Jacobs, J. (1974) Quantitative measurement of food selection. Oecologia 14: 413-417.

Krebs, C.J. (1998) Ecological methodology. Menlo Park, CA: Benjamin/Cummings.

Marchant, J.H., Hudson, R., Carter, S.P. and Whittington, P. (1990) Population trends in British breeding birds. Tring: British Trust for Ornithology.

Mason, C.F. (1998) Habitats of the song thrush Turdus philomelos in a largely arable landscape. J. Zool. Lond. 244: 89-93.

Mason, C.F. and Macdonald, S.M. (1999a) Habitat use by Lapwings and Golden Plovers in a largely arable landscape. Bird Study 46: 89-99.

Mason, C.F. and Macdonald, S.M. (1999b) Winter bird numbers and land-use preferences in an arable landscape in eastern England. Bird Conserv. Internatn. 9: 119-127.

Mason, C.F. and Macdonald, S.M. (2000) Influence of landscape and land-use on the distribution of breeding birds in farmland in eastern England. J. Zool. Lond. (in press).

Mason, C.F., Elliot, K.L. and Clelland, S. (1987) Landscape changes in a parish in Essex, eastern England, since 1838. Landscape Urban Plann. 14: 201-209.

Møller, A.P. (1983) Song activity and territory quality in the Corn Bunting Miliaria calandra; with comments on mate selection. Ornis Scand. 14: 81-89.

Pretty, J. (1998) The living land. London: Earthscan.

Pretty, J., Brett, C., Gee, D., Hine, R.E., Mason, C.F., Morison, J.I.L., Raven, H., Rayment, M. and van der Bijl, G. (2000) An assessment of the external costs of UK agriculture. Agric. Systems (in press).

Robinson, R.A. and Sutherland, W.J. (1997) The feeding ecology of seed-eating birds on farmland in winter. Pp. 162-169 in P.F. Donald and N.J. Aebischer, eds. The ecology and conservation of corn buntings Miliaria calandra. Peterborough: Joint Nature Conservation Committee (U.K. Nature Conservation, No. 13).

Shepherd, M., Hartley, I.R. and McGregor, P.K. (1997) Natal philopatry and breeding site fidelity of corn buntings Miliaria calandra on the Uists. Pp. 103-114 in P.F. Donald and N.J. Aebischer, eds. The ecology and conservation of corn buntings Miliaria calandra. Peterborough: Joint Nature Conservation Committee (U.K. Nature Conservation, No. 13).

Shrubb, M. (1997) Historical trends in British and Irish corn bunting Miliaria calandra populations: evidence for the effects of agricultural change. Pp. 27-41 in P.F. Donald and N.J. Aebischer, eds. The ecology and conservation of corn buntings Miliaria calandra. Peterborough: Joint Nature Conservation Committee (U.K. Nature Conservation, No. 13).

Siriwardena, G.M., Baillie, S.R., Buckland, S.T., Fewster, R.M., Marchant, J.H. and Wilson, J.D. (1998) Trends in the abundance of farmland birds: a quantitative comparison of smoothed Common Birds Census indices. J. Appl. Ecol. 35: 24-43.

Sparks, T.H., Parish, T. and Hinsley, S.A. (1996) Breeding birds in field boundaries in an agricultural landscape. Agric. Ecosyst. Environ. 6o: 1-8.

Wakeham-Dawson, A. (1997) Corn buntings Miliaria calandra in the South Downs and South Wessex Downs Environmentally Sensitive Areas (ESA), 1994-1995. Pp. 186-190 in P.F. Donald and N.J. Aebischer, eds. The ecology and conservation of corn buntings Miliaria calandra. Peterborough: Joint Nature Conservation Committee (U.K. Nature Conservation, No. 13).

Watson, A. and Rae, S. (1997) Preliminary results from a study of habitat selection and population size of corn buntings Miliaria calandra in north-east Scotland. Pp. 115-123 in P.F. Donald and N.J. Aebischer, eds. The ecology and conservation of corn buntings Miliaria calandra. Peterborough: Joint Nature Conservation Committee (U.K. Nature Conservation, No. 13).

Wilson, J.D., Morris, A.J., Arroyo, B.E., Clark, S.C. and Bradbury, R.B. (1999) A review of 
the abundance and diversity of invertebrate and plant foods of granivorous birds in northern Europe in relation to agricultural change. Agric. Ecosyst. Environ. 75:13-30.

Wilson, J.D., Taylor, R. and Muirhead, L.B. (1996) Field use by farmland birds in winter: an analysis of field type preferences using resampling methods. Bird Study 43: 320-332.

CHRISTOPHER F. MASON and SHEILA M. MACDONALD

Department of Biological Sciences, University of Essex, Colchester $\mathrm{CO}_{4}{ }_{3} S Q$, U.K.

e-mail:masoc@essex.ac.uk 